Renfang Tang*

\title{
East Meets West: Identity and Intercultural Discourse in Chinese huaju Shakespeares
}

\begin{abstract}
This article examines two huaju performances of Shakespeare-The Tragedy of Coriolanus (2007) and King Lear (2006), which are good examples of cultural exchanges between East and West, integrating Shakespeare into contemporary Chinese culture and politics. The two works provide distinctive approaches to the issues of identity in intercultural discourse. At the core of both productions lies the fundamental question: "Who am I?" At stake are the artists' personal and cultural identities as processes of globalisation intensify. These performances not only exemplify the intercultural productivity of Shakespearean texts, but more critically, illustrate how Shakespeare and intercultural discourses are internalized and reconfigured by the nation and culture that consume and re-produce them. Chinese adaptations of Coriolanus and King Lear demonstrate how (intercultural) identity is constructed through the subjectivity and iconicity of Shakespeare's characters and the performativity of Shakespeare's texts.
\end{abstract}

Keywords: huaju, Chinese Shakespeare adaptations, Coriolanus, King Lear, intercultural performance, identity, politics.

Foreign Shakespeare performances in different cultures offer new perspectives on the understanding and interpretation of the plays, and illustrate the on-going cultural exchanges between the playwright and the indigenous theatres as well as their audiences. In China, the majority of Shakespeare productions have been in the form of huaju 话剧 (spoken drama), a genre that developed in the early twentieth century on the model of contemporary Western theatre (Chen 1-55). Hua simply means “dialogue” and ju, “drama.” The term huaju emphasized dialogue as the primary artistic medium - a language of colloquial, everyday speeches that could comprehensively portray contemporary life and express modern ideas, as opposed to the ornate poetic language of verse and song in xiqu

* University of Hull, UK. 
戏曲 (sung-drama/traditional opera). Huaju was performed in vernacular Chinese and thus accessible to the masses, and had immediate political application. A genre born from the intercultural discourse between China and the West, huaju is an interesting field to explore the encounter of Western and Chinese cultures, ideology, conceptions, and aesthetics. Shakespeare is one of the major influences on the huaju theatre. During the twentieth century, Chinese practitioners accorded Shakespeare a special status among foreign playwrights.

This article will bring together intercultural theory and practice to make a close analysis of two huaju performances of Shakespeare, Da Jiangjun Kou Liulan (The Tragedy of Coriolanus, 2007), a Mandarin adaptation by Lin Zhaohua for the Beijing People's Art Theatre, and King Lear (2006), a Mandarin-English bilingual production by Chinese-British director David Tse Ka-shing. The two productions premiered at approximately the same time, and later toured China and the UK. They are good examples of cultural exchanges between the East and the West, integrating Shakespeare into contemporary Chinese culture and politics. Of more importance is that the two works provide distinctive approaches to the issues of identity in intercultural discourse. At the core of both productions lies the fundamental question: "Who am I?" At stake are the artists' personal and cultural identities as the processes of globalisation intensify. The question is as urgent for contemporary translators, directors, and audiences as it is for the protagonists in Coriolanus and King Lear. The study of these huaju adaptations allows us to re-examine and interrogate the dynamic intercultural relationship between Shakespeare and specific historical, cultural, socio-political, and dramatic contexts, and enables us to investigate the current condition of globalised Shakespeare. Chinese adaptations of Coriolanus and King Lear demonstrate how (intercultural) identity is constructed through the subjectivity and iconicity of Shakespeare's characters and the performativity of Shakespeare's texts.

\section{"I play the man I am": ${ }^{1}$ Coriolanus with Chinese Characteristics}

Coriolanus has received large critical attention in the West, especially in relation to its politics and the psychological complexity of the protagonist. Performances of the play have demonstrated similar concerns. By contrast, Chinese study on the play is scant, and rarely has Coriolanus been produced in the PRC. So far, there has been only one stage version (the 2007 adaptation titled Da Jiangjun Kou Liulan 大将军寇流兰 [The Great General Coriolanus] by Director Lin Zhaohua for the Beijing People's Art Theatre). Coriolanus was performed on the 20th and 21st of August in the Edinburgh Playhouse as part of the 2013

${ }^{1}$ The quotation is from The Tragedy of Coriolanus, 3.2.13-14. 
Edinburgh International Festival. ${ }^{2}$ What is attractive and modern is that two heavy metal bands-Zhixi 窒息 (Suffocated) and Tongyang 痛仰 (Miserable Faith)-are integrated into the performance. The production in Beijing and Edinburgh is not just about a Chinese director and a group of Chinese actors celebrating a particular love of Shakespeare. As an intercultural adaptation, it is about bridging cultures through mutual identification. For instance, the huge crowd scenes in Coriolanus are something with which many Chinese people would identify. The idea of a noble hero and the sacrifices of the individual for the betterment of a society are familiar to the Chinese audience, since there are many analogous figures in Chinese history. In addition, the motif of a dominant mother and her obedient son is also very Chinese, because in Chinese culture, filial duty is so important and audiences would certainly relate to Coriolanus's devotion to his mother-the only person who appears to have any real influence upon his decisions. In spite of the affinities, the elitism of Coriolanus and Volumnia, and the view of the masses as ignorant, selfish, corrupt, and easily manipulated are contrary to Mainland China's political ideology. What in Coriolanus attracted the director Lin was the alienated relations between the hero and the common citizens, which led to his downfall. Lin said to Andrew Dickson of The Guardian in an interview, "In ancient Rome, people admired

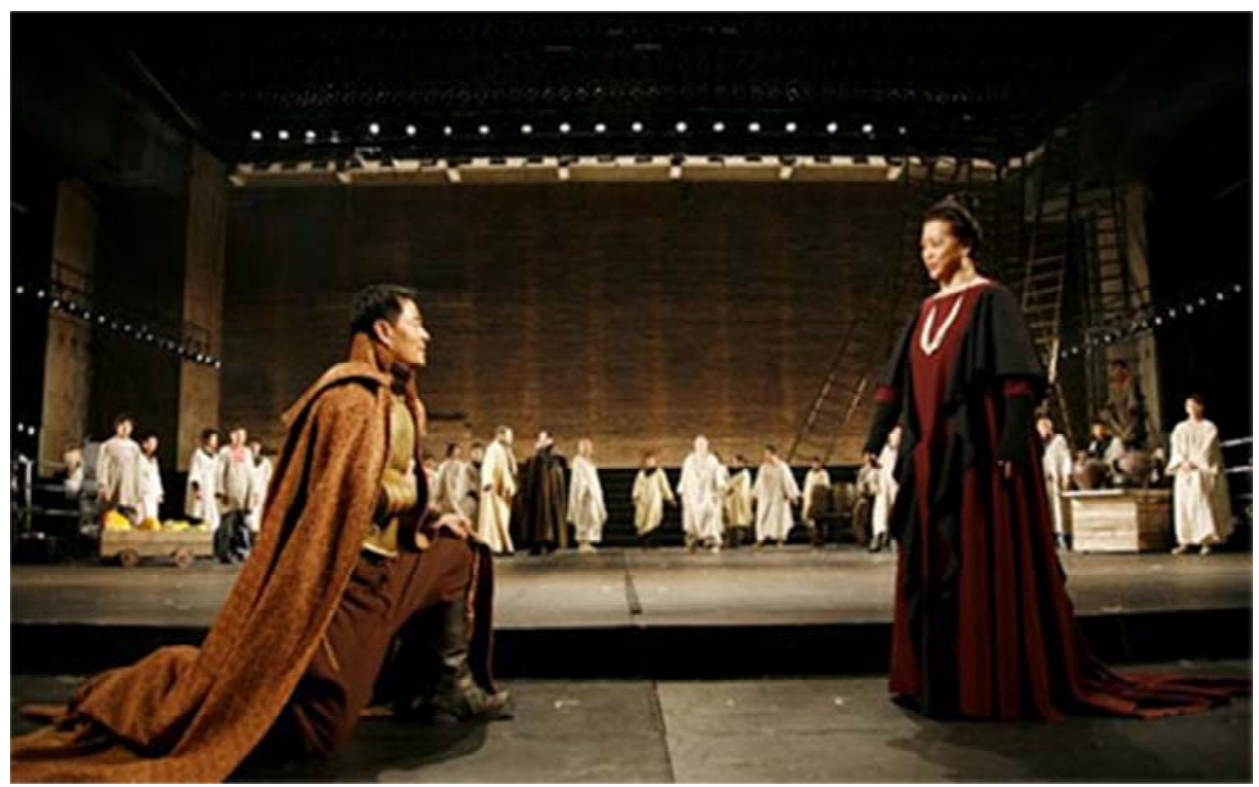

Figure 1. Pu Cunxin (Coriolanus) and Li Zhen (Volumnia) in The Tragedy of Coriolanus. (Courtsey of Beijing People's Art Theatre)

2 Programme notes. 
heroes. From my point of view, Coriolanus is a hero" (Dickson, 2013). The director had no purpose of pushing the common people onto the centre stage, as Bertolt Brecht did in the 1950s. What the production focused on was its tragic personae. The Chinese title of the production "Da Jiangjun Kou Liulan,” literally meaning "The Great General Coriolanus," refers to the Roman hero and conveys respect for the protagonist. Although it was set in ancient Rome, Lin agreed with Dickson that the play has a resonance with contemporary China, "It is a good phenomenon if the play refers to current events. Those in power like to control citizens, and some common citizens are foolish” (Dickson, 2013).

\section{The Shifting Politics}

Known as Shakespeare's most political play, Coriolanus, like the Chinese historical play Hai Rui Dismissed from Office emerging in mid-twentieth century China, ${ }^{3}$ is always politically sensitive and has strong echoes of contemporary society. At its core are the questions of authority, democratic franchise, freedom and submission that are of eternal relevance to the discussion of political ideals. The play's themes of popular discontent with government are dangerously contemporary. In Communist China, the resonances of the play can easily become explicit. Lin, however, has claimed not to be interested in politics or applying any particular agenda to his production. Lin prefers to embody his innermost personal world and aesthetics via various theatrical methods rather than to attempt to reflect political problems. Yet Coriolanus is an interesting choice for a director who repeatedly insists that he is not political, especially if viewed as part of the triptych of his other Shakespeare appropriations, his Hamlet (1989), and Richard III (2001). As scholars Li Ruru (2003) and Alexa [formerly Alex] Huang (2009) have explored in relation to Shakespeare in Mainland China, and Dennis Kennedy (1993) has explored in relation to

${ }^{3}$ Hai Rui (1514-87) was a Chinese official of the Ming Dynasty. In China he has been remembered as a model of honesty and integrity in office. A play based on his career, Hai Rui Dismissed from Office, gained political importance in the 1960s, during the Cultural Revolution. An article entitled "Hai Rui Dismissed from Office” was written by Communist Party official Wu Han in 1959 and later made into a Peking Opera play. Wu's play was interpreted by the Gang of Four member Yao Wenyuan as an allegorical work, in which the honest moral official Hai Rui representing the disgraced communist marshal Peng Dehuai, who was purged by Mao after criticizing the Great Leap Forward. According to Yao, the corrupt emperor in Wu's play represented Mao Zedong. On November 10, 1965, an article in a prominent Shanghai newspaper, “评新 编历史剧《海瑞罢官》” [A Criticism of the Historical Drama “Hai Rui Dismissed from Office”], written by Yao, began a propaganda campaign that eventually led to the Cultural Revolution. Yao’s campaign led to the persecution and death of Wu Han. 
political Shakespeare behind the Iron Curtain, sometimes simply the act of putting on a particular play is the political comment and metaphor.

What parallels can be drawn between Shakespeare's Rome and contemporary China? A reviewer of the performance at the 2013 Edinburgh International Festival found that there were "echoes of the Cultural Revolution in this Chinese company's Shakespeare” (Hoylewith, 2013). The programme notes for the Edinburgh run told audiences that the translator Ying Ruocheng's and the director Lin Zhaohua's shared interest in this play, about a leader devoured by the masses he arrogantly believes he is leading, could be attributed to their personal experiences in the Cultural Revolution-during which numerous short-lived demagogues from different factions were destroyed. The patrician ruling class both courts and despises volatile masses prone in their turn equally to street celebration and angry violence. The production thus emphasized the rise and fall of demagogues. While some spectators readily identified the tribunes with wretched and meddling functionaries in work clothes, the older generation saw in their diction and demeanour unmistakable references to the radical Revolutionary Committee members during the Cultural Revolution.

The production opened with hungry plebeians rising up against the Roman patricians for the mounting price of grain. In the performances in China, Lin recruited a hundred migrant workers, including plasterers, cooks, guards, and so on, to play the plebeians, clearly placing Roman history in the context of China today. The migrant workers, wearing sack-cloth tunics that could barely cover their work clothes, struck audiences as the most authentic people. With their shy, embarrassed, flabbergasted expressions, the migrant workers did not mean to be dramatic. These non-professionals stand for commonality not to be ignored. The hybridity of classic and modern struck the audience immediately as the rioting Roman plebeians were accompanied by three guitarists rocking and rolling onto the stage (Figure 2). The noisy music was not only a signification of rebellion, but also a symbolic voice of the angry crowds. Into this confrontation strode the arrogant martial hero Caius Martius (Pu Cunxin). The conflict between the plebeians and Caius Martius started from his first entrance, where he greeted the plebeians as "dissentious rogues, / That rubbing the poor itch of your opinion / Make yourselves scabs" (1.1.164-66). The opening scene made conspicuous the conflicting relationship between Coriolanus and the common people. The latter called Coriolanus the "chief enemy to the people" (1.1.5-6), thought it a threat for their life to have Coriolanus in their country and resolved to get rid of him. Although they recognised his merit on wars, they could not bear his pride any longer. The protagonist stood aloof against the citizens, which showed his alienation and foretold his downfall. Dramatic tension was sustained as to what would become of this riot and how the avant-garde application of band music by the director would fit into the performance. 


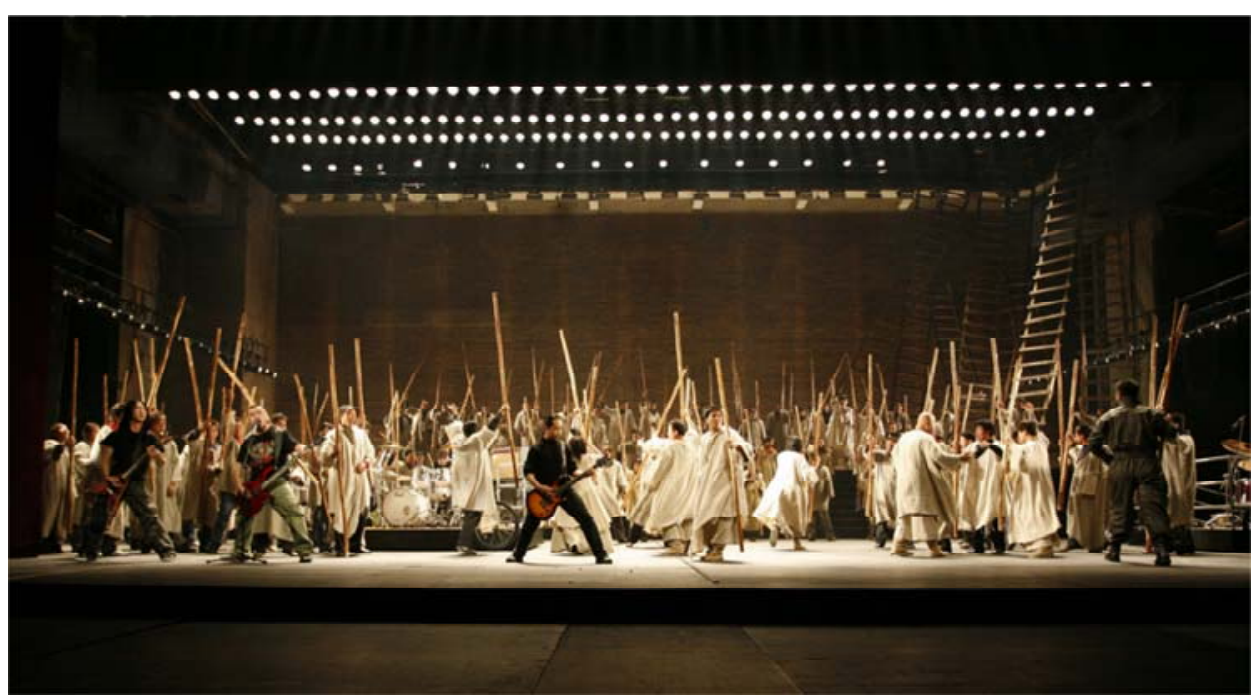

Figure 2. The Tragedy of Coriolanus by the Beijing People’s Art Theatre

In presenting the confrontation between the citizens and Coriolanus, it was perhaps not difficult for the Chinese migrant workers to play the plebeians of Rome en masse, as they were presenting their own identities on the Chinese stage, in other words, playing the men they were. Like the seventeenth-century England, in today's rural urbanization in China, millions of farm labourers have been forced off their farms, flooding into cities and becoming the so-called migrant workers. They make a living in the cities by working long hours but getting low wages. A new industrial working class, transformed from agrarian labourers, has therefore come into being in Chinese society.

In China today, practitioners of pure art profess to be independent from everything they place under the rubric of politics. However, this loudly expressed desire for freedom from a defunct ideology is just a facile ploy to cover their inability to commit to any cause, or to make any intellectual impact. To compensate for an ineffectuality of mind, they emphasize aesthetic appeal. While the Chinese Coriolanus is a conventional interpretation in the eyes of many Western critics, its mise-en-scène has been influenced by traditional Chinese theatre, which did not come across adequately to the Western audience.

\section{Simplicity of the Stage}

Designed by Yi Liming, the stage presenting the Roman tragedy was very simple. With white lighting, a bare stage stretched all the way to the brick walls at the rear, beside which leaned several scattered ladders. The climbing up and 
falling of men at the backdrop enacted an imagination of soldiers launching attacks onto the city wall. The design had absorbed not only Western aesthetics, but also the essence of traditional Chinese theatre, specifically the assumptive nature of the stage. In traditional Chinese theatre, as well as in Western spoken drama, actors are the emphasized centre of the stage, whose performance should be integrated with setting and music. Jerzy Grotowski defines the theatre as: "what takes place between spectator and actor," so that "all the other things are supplementary-perhaps necessary, but nevertheless supplementary” (Grotowski 982). Peter Brook also defines theatre as the interaction between actor and spectator: "I can take any empty space and call it a bare stage. A man walks across his empty space whilst someone else is watching him, and this is needed for an act of theatre to be engaged" (Brook 7). He further develops his idea in The Open Door: Thoughts on Acting and Theatre and puts forward the notion that if a theatre director wants to compete with a film director, he has to adopt empty space instead of a realist setting (Brook 39). Lin's simple stage, in a way, bears resemblance with Grotovski's “poor theatre” or Peter Brook's "empty space," whose stage, unlike the realistic stage, which attempts to create an illusion of life, is often bare of decorations. However, the idea of Yi Liming's design, I believe, did not derive from Grotowski or Peter Brook, but from the tradition of Chinese theatre. For Coriolanus, Yi divided the stage space into three parts: the apron stage, the centre and the back stairs. On the apron stage (see Figure 3), there was a long wooden table with seven chairs behind and two

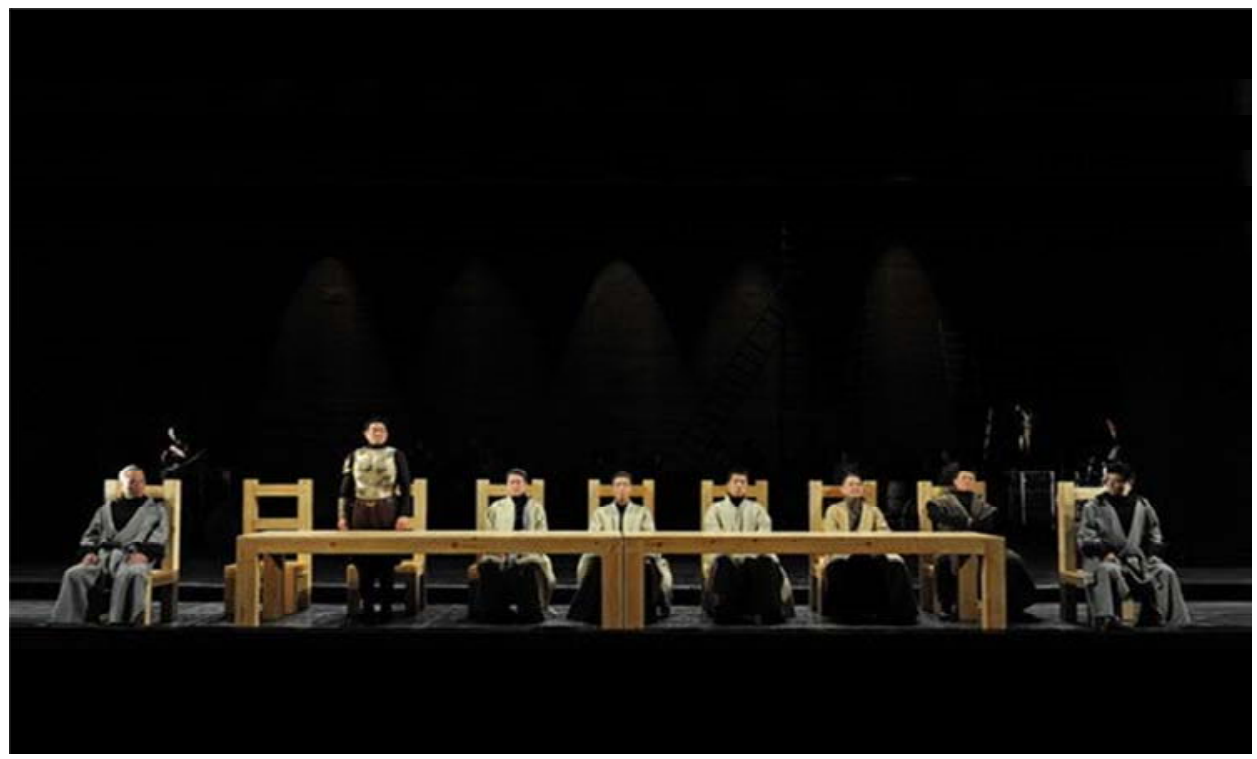

Figure 3. The Apron Stage in The Tragedy of Coriolanus 
on both sides, all facing the audience. This arrangement was adopted twice to set the capitol of either Rome or Volsce. When the table and chairs lowered and became invisible to the audience, the apron stage joined the main stage and the spot before it then turned into a battlefield to hide the Roman soldiers. Above the centre stage, a five-column movable frame could rise up to symbolise either the city wall of Corioles or the Roman capitol in the scene of Coriolanus's triumphant return. On the back stage, there were several ladders leaning against the backdrop, suggesting the inside of Corioles or the market place where citizens gather. Lin's simple stage, similar to the empty stage of traditional Chinese theatre, ensured flexibility in narration. It projected an ensemble of theatrical codes, open to interpretation. The stage space was at the same time the icon of a given social or socio-cultural space and a set of signs aesthetically constructed in the manner of abstract painting (Ubersfeld 101). While leaving room for the audience to reflect upon what they perceived, the assumptive nature of Lin's stage produced spatial metaphors to serve the purposes of his adaptation.

\section{Estrangement Effect in Acting}

In the Chinese Coriolanus, instead of creating the illusion of the war scene, Lin chose to demonstrate it by means of the Brechtian estrangement effect. The estrangement effect (German: Verfremdungseffekt, or simply V-effect), more commonly known (earlier) through John Willett's 1964 translation as "the alienation effect," is a performing arts concept developed by Bertolt Brecht. To alienate an event or character, in Brecht's view, means to strip the event of its self-evident, familiar, obvious quality and create instead a sense of astonishment and curiosity about events, so as to show at once their present contradictory nature and their historical cause or social motivation (Brooker 215). In 1935, Brecht saw a Peking Opera performance in Moscow by famous female impersonator Mei Lanfang (1894-1961), and ultimately confirmed the realization of his theories of Verfremdungseffekt taking the example of Chinese performance art. In a famous essay on "Alienation Effects in Chinese Acting" published in 1936, he described the effect as "playing in such a way that the audience was hindered from simply identifying itself with the characters in the play. Acceptance or rejection of their actions and utterances was meant to take place on a conscious plane, instead of, as hitherto, in the audience's subconscious” (Willett 91). Thus, the Brechtian theory of Verfremdungseffekt owes much to xiqu戏曲 (Chinese opera), to which Lin Zhaohua has also paid tribute. For Brecht, Chinese opera seemed so unrealistic that he assumed that both the actor and the audience were distanced from emotional involvement and freed for critical, rational analysis (his major interest). However, what seemed 
strange and unemotional to Brecht was moving and believable to the Chinese. Many Chinese theatre artists and theorists advocate a frontal, presentational acting style, episodic structure, the dialectical juxtaposition of disparate ideas and elements, and a clear awareness of theatre as theatre (manifest in such strategies as stylised gestures, mime, on stage musicians, direct address to the audience, song). Highly influenced by the theatrical traditions of xiqu, Lin Zhaohua required actors in Coriolanus to "be" the characters they play and at the same time to keep a distance from them (Lin 55). While seeing the performance, audiences could obviously notice traces of the characters' acting. In the battle scene at the city of Corioles, Coriolanus delivered his encouragement or rather his threats to his Roman soldiers in a carelessly detached manner. He calmly watched his soldiers rushing into the battlefield and stood with his back to them. Likewise, his counterpart, the Roman general Titus Lartius remained in silence, stage left. The battle started without their active participation. Five Volscian senators, who stood on the platform hanging above centre stage to indicate the city gate of Corioles, shook their heads and bodies as reactions to the seeming attack. When the Romans began to retreat out of fear, Coriolanus cursed them even more severely than before, calling them curs, "souls of geese/ [t]hat bear the shapes of men" (1.4.34-35). However, the actor Pu spoke these lines quickly but not angrily as Shakespeare's text indicates, as if he was not really offended by the coward crowd. Coriolanus then led another charge, was shut into the city, and fought all alone. Upstage, audience members witnessed his slowed-down

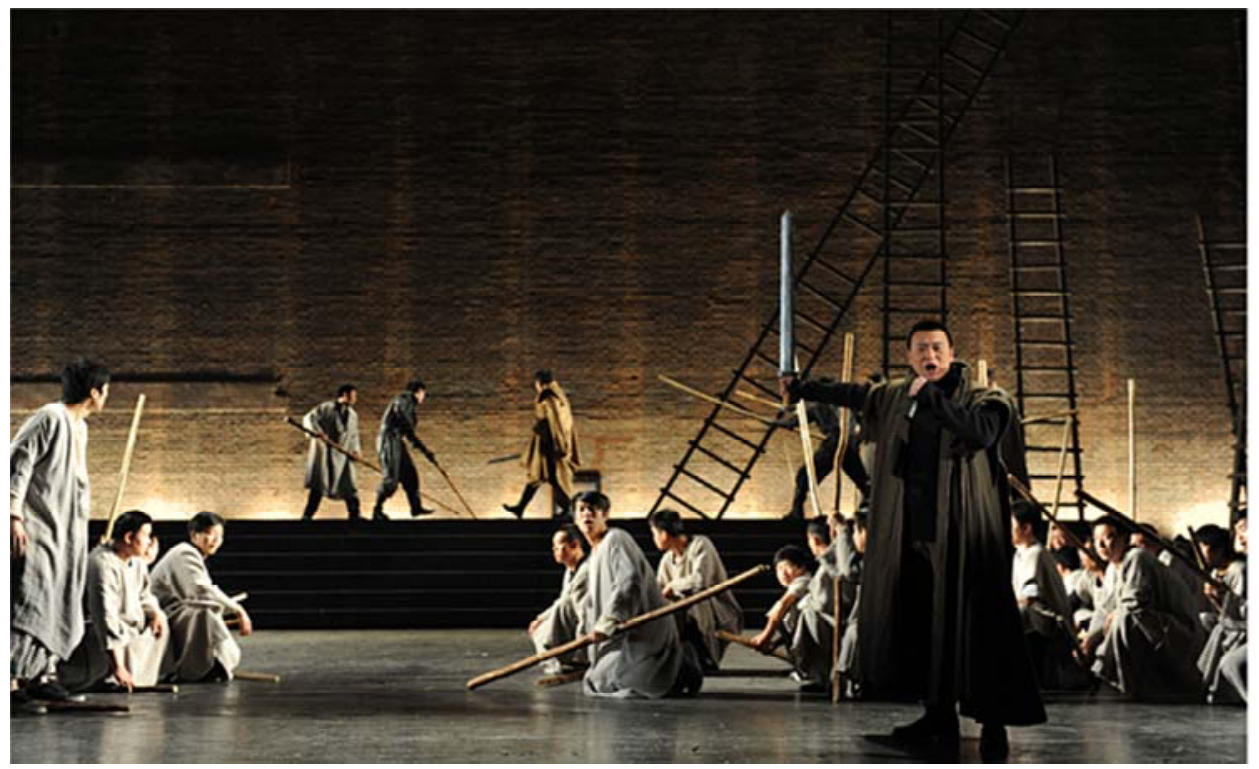

Figure 4. The war scene in The Tragedy of Coriolanus. Photo credit: Huang Zhe / Xinhua 
combat with the Volscians. Through making strange the performance, the director therefore provoked, in his audiences, reflections on what they would in Naturalistic theatrical conditions have normally taken for granted. Inspired by the stylised acting of xiqu performance, Lin's production did not create the illusion of the war full of blood and danger, but held the attention of audiences upon the actors in performance, rather than commenting on the war itself.

\section{Heavy Metal as Soundtrack}

The most discussed innovation was Lin Zhaohua's incorporation of two heavy metal bands, Miserable Faith and Suffocated, into the production, used not only as incidental music but as a metaphorical battle of the bands between Coriolanus/the Romans and Aufidius/the Volscians. The two bands were pulled on and off stage on bare metal platforms, creating a visual battle of the bands, representing the tension between the common people of Rome and the reigning nobility who must ultimately work for the voices of the powerful masses. The metal score created punctuation for the battles and the bloody politics of Coriolanus, interjecting riffs to create drama and tension.

Both in its performances in China and at the Edinburgh International Festival, the use of two heavy metal bands in this Shakespeare production received much critical attention and many voices were heard. Dominic

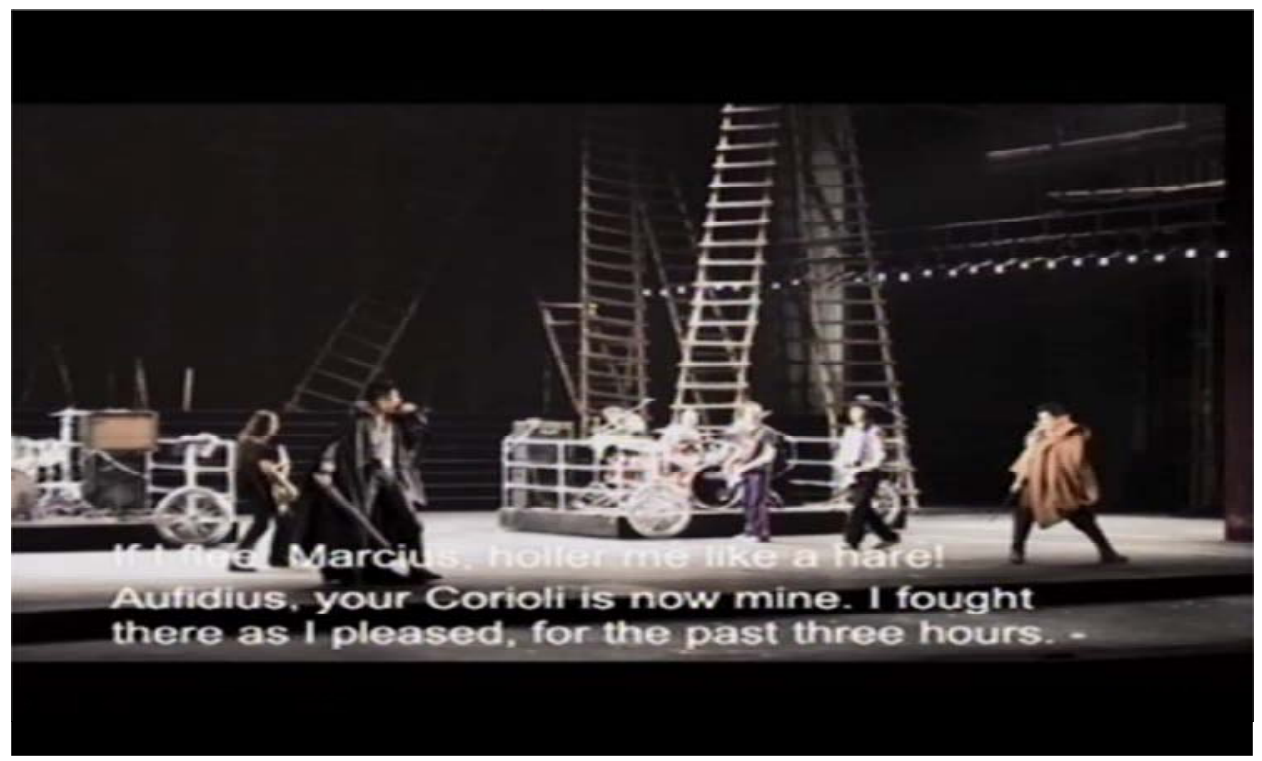

Figure 5. Pu Cunxin (Martius) and Jing Hao (Aufidius) combat with microphone in The Tragedy of Coriolanus 
Cavendish of The Telegraph found it an "arresting concept" evoking "China's tumultuous embrace of Western influences" (Cavendish, 2013). However, Brian G. Cooper of The Stage complained that in Lin's Coriolanus, a production transferred from Beijing (unlike the National Theatre of China's Richard III devised for 2013 Globe to Globe), the "uniquely Chinese theatrical influences are conspicuously absent throughout (Cooper, 2013). These rock bands reminded me of the musicians in Peking Opera, who often sit on stage left, wearing normal street clothes. Chinese audiences are quite familiar with seeing the musicians appearing on the stage together with the actors. While lutes and flutes often accompany Shakespeare, musicians of Peking Opera play jinghu, a small, high-pitched, two-string spike fiddle, to accompany performers during songs, and they clash cymbals whenever a general or king enters the scene. Therefore, this supposedly Western-style production is rather more Chinese than some critics give it credit for.

To sum up, Lin appropriated Shakespeare's Roman play on modern Chinese stage to cater for local audiences' understanding. Not only did all the characters speak Mandarin as an identity of Chinese Shakespeare, but also there were obvious Chinese characteristics: the images of migrant workers as citizens and the influence of traditional Chinese theatre on its mise en scène, which familiarize the Chinese audience with the Western other. The irony of the plebeians who have a power that they have no power to claim for can be identified from the migrant workers who in a people's republic are still living marginalized lives. The simplicity in the stage design emulated that of the traditional Chinese opera stage. Modern acoustic techniques, i.e. heavy metal, brought about the effect of disharmony. The ancient Shakespearean setting mirrored modern globalising society. The old philosophical question of "who am I" is re-enquired repeatedly when individuals are struggling for a clear identity. Lin's presentation of Coriolanus's titular-self projects a common dilemma in modern society, in which there is a duality between what might be considered by any given individual as ideal and what is politically and socially expedient and practical. Coriolanus's failure in "authoring the self" reveals the stupidity of modern man as an existential being, who believes in the freedom of the construction of identity by the individual, unhampered by the constraints of the political ideologies and power structures within which his existence is embedded. For the director, it was a successful endeavour to appropriate this less-performed Shakespearean play for the modern Chinese stage. Lin's production not only enriches Shakespearean scholarship in China; providing a Chinese vernacular in the global market of Shakespearean performances, it also sets an inspiring example for intercultural theatre practice in the future. 


\section{“Tell me who I am”: ${ }^{4}$ Searching for Identity in a Bilingual King Lear}

Bilingual and multilingual theatre is a new form of Shakespeare performance that has emerged in the past few decades. As directors and theatre companies move ever more freely across national boundaries, linguistic difference is called upon to be the marker of the contentious space between cultures. As a play about the emptiness of words and the failure of language to express the existential angst of naked human existence, King Lear is a useful platform for experiments with multilingual theatre. The problematic nature of cultural re-inflection, marked through strategies of linguistic deferral, continues to resonate in BritishChinese director David Tse's 2006 Mandarin-English production of King Lear. Co-produced by Tse's London-based Yellow Earth Theatre ${ }^{5}$ and the Shanghai Dramatic Arts Centre, it was an exhilarating but challenging collaboration between artists from completely different cultural and linguistic backgrounds. Following Shakespeare's text with a modern twist, interwoven with Chinese lines based on Zhu Shenghao's translation, it brought together a mixed cast of Chinese and British actors to perform in their native tongues and explore the question of the translatability of cultures. Tse relocates Lear's story to a futuristic Shanghai of 2020, which is set as one of the world's business and financial centres. Lear is a wealthy and powerful Chinese tycoon whose business empire spans continents. In his Shanghai penthouse on the 188th floor, Lear calls a video conference to decide how his global business empire will be divided among his three daughters. While justifying their inheritance, the two elder sisters flatter their father in elegant Chinese but English-educated Cordelia, no longer fluent in her father's tongue, says "Nothing." The loss of face sends Lear into a spiral of fury and madness. Hence, the story of Lear became one of both domestic struggles and international corporate wars. The audiences were led into a vicious and visceral world where greed and ambition turn sister against sister, and child against parent. The supposedly more civilized world that is closer in time to the world of the audience than either Shakespeare's England or his historical setting for Lear is still just as haunted by betrayal, lust and murder as Shakespeare's.

${ }^{4}$ The quotation is from King Lear (1.4.34).

${ }^{5}$ A touring theatre company, established in 1995 by five British East Asian performers to raise the profile of British East Asian theatre. The company tours nationally and internationally, and produces quality ensemble physical work, using performing traditions of east and west and to celebrate the meeting of different cultures. It has become the UK's only revenue-funded British East Asian touring theatre. 


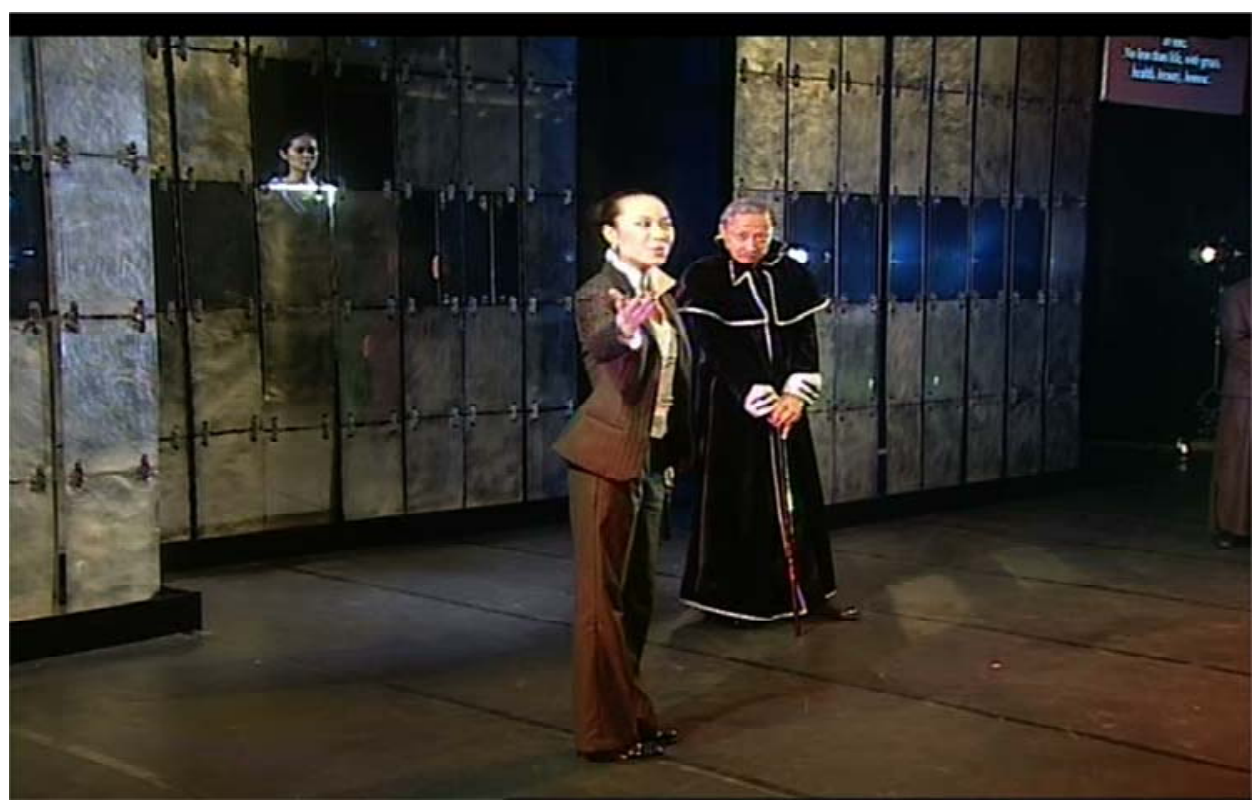

Figure 6. The love test scene in King Lear, dir. by David Tse, 2006

Such a version of King Lear attaches importance to the issues of cultural identity for diasporic communities in the increasingly globalised world today. Tse explains, "Set in a future Shanghai and London, when those with power and money live above the law, the play is in many ways an exploration of Chinese and British identities” (Baxter, 2006). The production reframes the gap between a Chinese Lear and an English-educated Cordelia in terms of linguistic difference and highlights the difficulties of intercultural and intergenerational exchange. Providing a challenging cross-cultural interpretation, East meets West in this exploration of Chinese and British identities, Confucianism, Taoism, Buddhism, spiritual and financial wealth, family loyalty, and generational divides.

\section{The Macaronic Stage}

Tse's bilingual King Lear is the type of macaronic performance defined by Marvin Carlson. Regarding the definition of a "macaronic stage," Carlson explains,

The model of a monolinguistic congruence between play and audience, requiring translation into a parallel language when the target audience changes, is so familiar that it might appear almost universal, but in fact nearly every 
period of theatre history offers examples of plays that utilize more than one language, and our own era is particularly rich in the number and variety of multilanguage performances. Such plays might be called "macaronic," a term first coined to characterize Renaissance texts that mixed Latin with vernacular languages, but later used for any text employing more than one language. (Carlson 16)

Settling the story in an intercultural context, with actors performing in Mandarin Chinese and English (with surtitles) and creating a cosmopolitan atmosphere, ${ }^{6}$ Tse's King Lear represents a new breed of Asian-European Shakespeare in what might be called the "post-national" global Shakespeare industry. As a bilingual and bicultural performance, it provides a different experience than those more traditionally defined foreign Shakespeares.

Using a mixed cast of Chinese and British (including British Asian) actors, Tse explores the promise and perils of globalisation in the context of local conditions of translation, highlighting the themes of miscommunication and intergenerational conflict. Half of the cast members were native Englishspeakers while the other half mainly spoke Mandarin Chinese. Lear is played by the distinguished Shanghai actor Zhou Yemang. The British-born actor David Yip-whose family roots are from Southern China-doubles up as Gloucester and Albany. From the beginning to the end, Zhou Yemang's Lear commanded a powerful presence on stage, but other actors had some rough moments because they were required to switch back and forth constantly between their native tongue and a foreign language. Some dialogues could be challenging to follow because actors switched between the two languages in the same block of lines or even mid-sentence. The performance embodies the tensions between different linguistic spaces marked off by the bilingual dialogues and the bilingual surtitles. The dialogues and surtitles compete for the audience's attention and often intrude into each other's processes of signification. Tse's arrangement of linguistic texts prominently highlighted the felt pressure of cultural difference and displacement. The actors' performances of alternating speech patterns, rhythms and cadences actively embodied such anxieties, particularly because none of them was bilingual actor in this demanding bilingual production that required British and Chinese actors with training to share the same stage.

6 The bilingual feature became a major source of complaints for some reviewers. See, for instance, Huang's reviews in Shakespeare 3.2 (August 2007): 239-42, and in Theatre Journal 59.3 (2006): 494-95, and Claire Conceison, "Huang Zuolin Festival (Review)," Theatre Journal 59.3 (2006): 491-93. At the same time, the style of the Chinese translation of Lear - a version that was translated by Zhu Shenghao in 1943 and was popular in China-was criticized by Conceison (492) for its "jarring contrast to the poetic English version.” 
The play opened with an updated division-of-the-assets scene. Set in the Shanghai penthouse office of the modern Lear's transnational corporation, the scene involved a creative re-interpretation of the miscommunication in Lear's famous test of love. The opening scene immediately set up an intercultural scenario, where elements from different cultures were juxtaposed and different languages used. Lear is a Shanghai-based business tycoon who solicits confessions of love from his three daughters. Lear, Regan and Goneril spoke fluent Mandarin Chinese, but the English-educated Cordelia, a member of the Chinese diaspora living in London, was no longer proficient in her father's language. Joining the conversation from behind a semi-transparent screen that represented a video link from London (Figure 7), she is both physically and culturally remote from the rest of the characters at the meeting in which family affairs and business coalesce. As Goneril and Regan carried on their confession of love, Chinese fonts projected onto the screen panels and onto Cordelia's face. Immersed in oppressing Confucian values that implicate family roles into the social hierarchy, Lear insisted upon patriarchal authority and respect from his children. The test of love becomes a process of reaffirmation of one of the key Confucian virtues: filial piety.

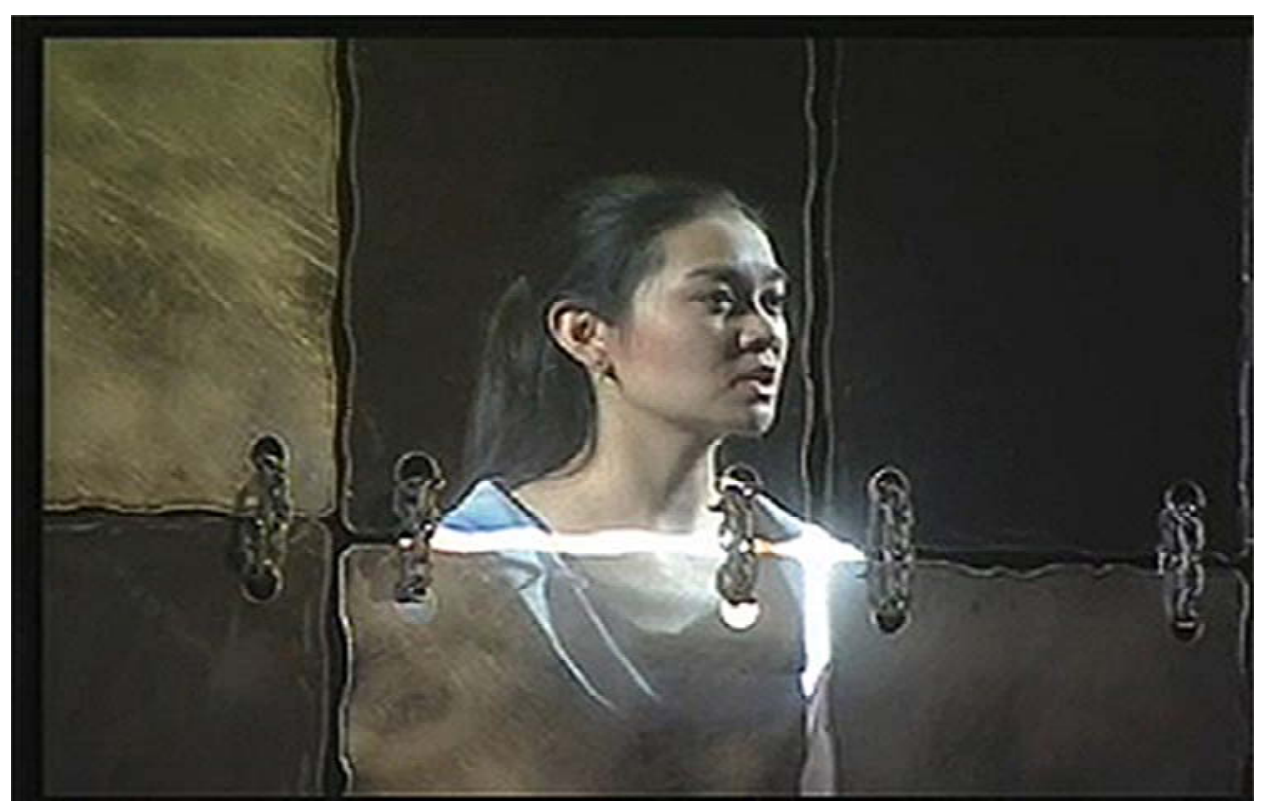

Figure 7. King Lear, dir. by David Tse, 2006: Cordelia (Nina Kwok) replies to King Lear

As the love test scene exemplifies, bilingualism onstage is deployed as a symbol of the failure of assimilative Westernisation as the dominant form of globalisation, sensitising the audience to various assumptions of Anglo- 
universalism. Throughout the performance, the majority of the audience could only follow one part of the dialogue with ease and had to switch between the action onstage and the surtitles. Translation thus acted in this production as both a metaphor and a plot device, such a multilingual Shakespeare being no less effective than plot parody in laying bare the process of relocating meaning within local theatrical cultures.

\section{Juxtaposition of Eastern-Western Cultures}

Tse's Lear is not only bilingual but also bicultural, which enables it to explore the question of the translatability of cultures through juxtaposition of cultural references and a mixture of traditional and modern elements. The adaptation employed Buddhist-themed music, future-retro costumes with both Western and Chinese features, an ensemble cast with significant doubling and cross gender casting, mobile phones, text-messaging, aerial work, multimedia elements, and jingju 京剧 (Peking Opera) percussion patterns and movements to embody the performative anxieties of diasporic artists as well as the uneasy coalition between radically different cultures. A scene capitalising on the presence of two cultures was the duel between Edgar and Edmund. Following the rhythms of Peking Opera percussion beats, the actors engaged in a highly stylised ritualistic

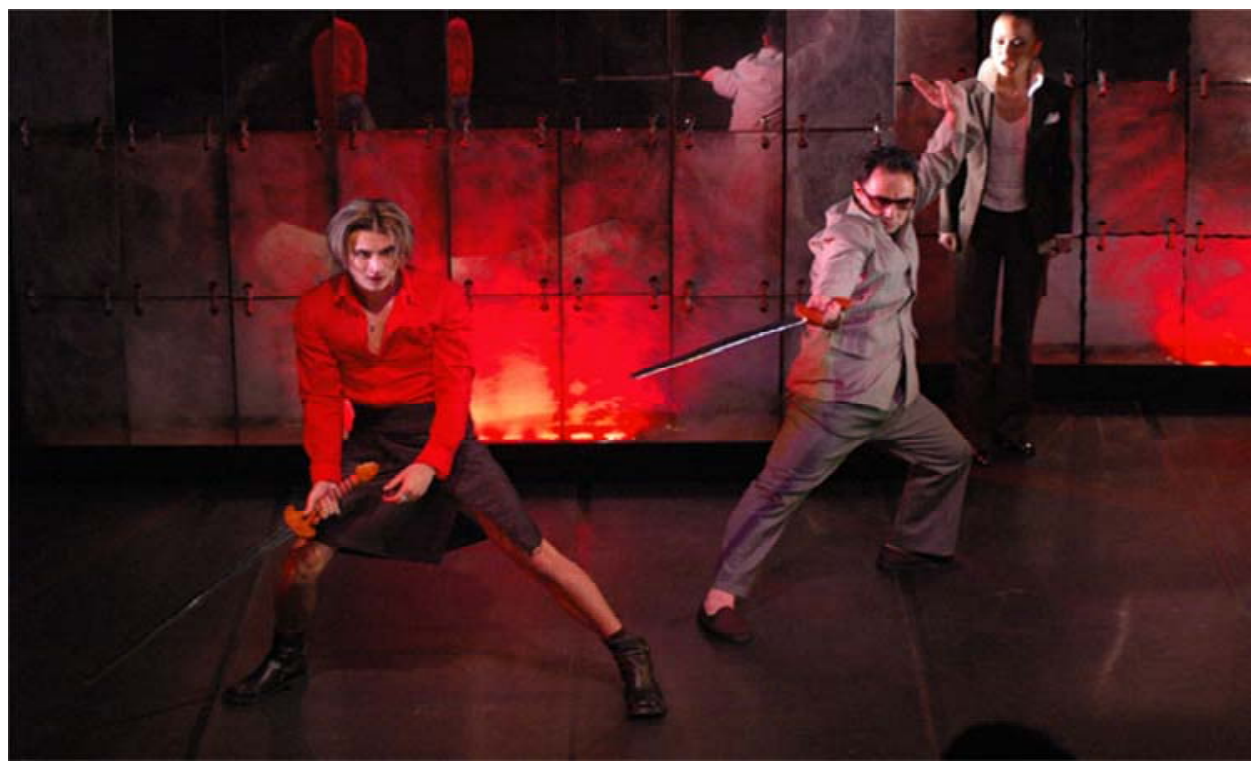

Figure 8. Edmund (Matt McCooey) and Edgar (Daniel York) duel in the MandarinEnglish King Lear, directed by David Tse, 2006. (Courtesy of Yin Xuefeng and Shanghai Dramatic Arts Centre) 
fight using flick knives. Their movements evoked both English sword-fighting and the combat styles seen in Peking Opera.

Tse's King Lear foregrounded intercultural discourse not only through hybrid performance idioms and uses of two languages, but also through scenography and costumes. The set and costume designs were influenced by Taoist concepts of yin and yang, masculine and feminine, hard and soft, light and dark. Performed in the Cube at the Royal Shakespeare Theatre, an innovative makeshift black-box theatre constructed in the auditorium while the RST was undergoing renovation, Tse's King Lear took advantage of the intimate stage. Entering the theatre, the audience saw a brightly lit open stage with sparse scenery within close proximity of the seats. At centre stage stood three interlaced floor-to-ceiling screens made of rectangular reflective panels. Most of the actions took place in front of the screens, which were transformed through lighting from a regal façade to a semi-transparent video screen to the wilderness for the storm scene. The Buddhist notion of redemption and reincarnation informed some of the design elements and presentational styles. The production opens and closes with video footage, projected onto the three interlaced floor-toceiling reflective panels, that hints at both the beginning of a new life and life as endless suffering. Images of the faces of suffering men and women dissolve to show a crying new-born baby held upside down. If the stage design suggested Taoist simplicity and postmodern minimalism, the costumes evoked a fusion of Chinese and Western elements, inspired by both Western high-fashion styles as well as garments from Peking Opera.

\section{Thematic Problematics}

One of the main emphases in Tse's King Lear is the problem of communication between generations, a topic exacerbated by the older generation's belief in the father as a kind of "king," i.e. an absolute authority of the family. Set in an intercultural context, King Lear offered a good opportunity for Tse to explore "the potential for misunderstanding between a Chinese Lear, with his Confucian values, and an English-educated Cordelia no longer fluent in her father's tongue and reduced to saying 'nothing"' (Jones, 2006). The production therefore highlighted different values between generations reflected in the father-daughter relationships, and revolved tightly around the financial wars later mounted by Goneril and Regan against their father.

This production was not only about miscommunication, but also celebrated a longing for contemporary universality, filtered through a particular cultural experience, which could then be applied to more universal experience. Tse's efforts to employ a wide array of cultural references in order to portray an intercultural scenario might seem to evoke a term from Gilbert and Lo- 
"cultural cosmopolitanism"- a disposition marked by "openness to divergent cultural influences as well as practices of navigating across cultural boundaries" (Gilbert and Lo 8). It provided a chance for the East Asian actors to perform the classics, a chance to be heard. The play is close to the heart of the BritishChinese director David Tse, who believes that Lear speaks strongly of diaspora artists and audiences who maintain links, but are unable fully to communicate, with their families residing in their home countries. In an interview, Tse says, "There are misunderstandings in a family of immigrants where the elder immigrants have difficulties in communicating with their children" (Liang 289297). One of the barriers within the immigrant families, such as the overseas Chinese ones, is perhaps language. While the younger generation are fluent in English, their parents, the first-generation immigrants, usually have problems. Tse's approach in directing King Lear was informed by his own personal relationship with his parents. In particular, his experiences of growing up in an immigrant Chinese family in Britain were pivotal for his individual connection to King Lear. Drawing from his own family's circumstances, Tse felt an affinity to Cordelia, who chooses to bite her tongue and say nothing. He also saw parallels between Lear and his father. Using the experience inherited from his family, David Tse wished to communicate to his British audience about the East.

Nevertheless, amid the intended themes there was one dimension that was ostensibly missing-namely, the potential political associations of the original play. The direction of the opening love-test scene is illustrative in this aspect. Terence Hawkes suggests that the "emblematic force" of Shakespeare's King Lear is witnessed during the staged map-reading and the accompanying territorial partition of the kingdom in the opening scene (Hawkes 121). And, in the context of Chinese politics, as Rossella Ferrari comments, such issues in Lear can be taken as inadvertent "allegories of inter-Chinese power balances" that are fraught with internal conflicts as well as the risk of dissolution (Ferrari 61). However, the political theme of territorial division and the disintegration of a kingdom was not made clear in Tse's King Lear. The result, as discussed above, was an interpretation of the Lear story in terms of family events and financial wars. Gone were the idiom of national territories and the famous mapreading scene. Instead, sibling rivalries and intergenerational gaps were presented against the backdrop of stiff competition in profit-driven capitalism. Goneril and Regan were credited with Chinese renminbi and US dollars at the end of their love tests, while British pounds were taken out from Cordelia's bank account in London. Near the end of the production, the final battlefield was changed from Dover to the Shanghai Stock Exchange Centre, where a spectacular financial war was being waged between "Lear International" led by Cordelia, and the joint force of the "Goneril Group" and "Regan Regina."

To sum up, Director David Tse's King Lear was initially informed by his personal experiences as well as by his belief in the "universal aspects" of the 
Lear story. The bilingual feature of Tse's King Lear, and the free use of diverse cultural references helped to construct a cosmopolitan atmosphere that allowed the story of a Chinese Lear to unfold in a globalised city. By engaging in such intercultural evocation, the production challenged the viewer to reconsider the conventionally accepted boundaries between cultures and successfully settled the story of Lear into a context that appeared receptive to cultural diversity. Nevertheless, such a portrayal is not without its own blindness. As I have demonstrated, a kind of depoliticization can be perceived in the omission of the scene of territorial division, important thematically in Shakespeare's play, and the substitution of the story of a disintegrating business empire. Such an adaptation not only pointed towards what a Chinese Lear may have meant for the director personally, but also highlighted constraints that perhaps have to surround attempts to stage a play such as King Lear in contemporary China.

\section{Conclusion}

Although Shakespeare does not rank as the most important playwright in shaping modern Chinese theatre, huaju is undoubtedly the most popular form of Shakespeare performance in China. As Li Ruru says, "the story of Shakespeare in China is more about China than Shakespeare" (Li, "Millennium Shashibiya" 185). Shakespeare in China has shifted and transfigured according to China's changing political and cultural circumstances. Chinese Shakespeare presents a very interesting example of how the study of intercultural Shakespeare performances in Asia cannot be removed from history, as China's transformation from a monarchy in the Qing Dynasty, to a Republic, and later to a Communist state has impacted the many re-presentations of Shakespeare in the past and influences the Shakespeare that China knows today. This reminds us that the change in theatre and the attitudes towards Shakespeare appropriations are always tied to political ideologies and cultural agendas, and do not represent straightforward examples of artistic progression.

Lin Zhaohua's Coriolanus and David Tse's bilingual King Lear illustrate the cultural encounter between the East and the West and inspire questions about individuals and their wider cultural identities. Incorporating resources from both Western and traditional Chinese theatre, Lin's Coriolanus shows that the intersection where the East meets the West can bring out an extraordinarily new form of performance. The bilingual production of King Lear exemplifies how Chinese heritage can create Shakespeare in a way that enables both Chinese and British audiences to explore possibilities for the Western canon to reflect upon a foreign culture that is now integrated with the UK. Both productions explore the issue of personal and wider social and political identity through relating Shakespeare with contemporary life. Tse saw the question of 
identity in an age of linguistic globalisation as one without fixed answers; while Lin's Coriolanus told the tale of a lonely individual alienated by modern society. The two productions not only demonstrate the opportunities afforded by the hundred-year development of Chinese spoken drama, but also point towards the new direction of contemporary China and Chinese modern theatre.

\section{WORKS CITED}

Baxter, Lew. "Shanghai Meets Shakespeare.” Daily Post/Shanghai Star/China Today. 22 November 2006.

Brook, Peter, The Empty Space. New York: Simon \& Schuster Inc., 1968. 布鲁克, 彼得. 敞开的门: 谈表演和戏剧. 于东田译. 北京: 新星出版社, 2007. [Brook, Peter. The Open Door: Thoughts on Acting and Theatre. Trans. Yu Dongtian. Beijing: New Star Publishing House, 2007.]

Brooker, Peter. "Key Words in Brecht's Theory and Practice of Theatre." The Cambridge Companion to Brecht. Ed. Peter Thomson and Glendyr Sacks. Cambridge: Cambridge University Press, 2006. 209-24.

Carlson, Marvin. "The Macaronic Stage.” East of West: Cross-cultural Performances and the Staging of Difference. Ed. Claire Sponsler and Xiaomei Chen. New York: Palgrave, 2000. 15-31.

Cavendish, Dominic. "Edinburgh Festival 2013: The Tragedy of Coriolanus, review." The Telegraph. 21 August 2013. http://www.telegraph.co.uk/culture/theatre/ edinburgh-festival/10257093/Edinburgh-Festival-013-The-Tragedy-of-CoriolanusPlayhouse-review.html. 8 September 2018.

Chen, Xiaomei, ed. and intro. The Columbia Anthology of Modern Chinese Drama. New York: Columbia University Press, 2010. 1-55.

Conceison, Claire. "Huang Zuolin Festival (Review)." Theatre Journal 59.3 (2006): 491-93.

Cooper, Brian G. "Edinburgh International Festival: The Tragedy of Coriolanus." The Stage Reviews. 22 August 2013. http://www.thestage.co.uk/reviews/review. php/38849/edinburgh-international-festival-the-tragedy. 18 September 2018.

Dickson, Andrew. “Guitar hero: Coriolanus goes rock.” The Guardian. 6 August 2013.

Ferrari, Rossella. "Transnation/transmedia/transtext: Border-crossing from Screen to Stage in Greater China.” Journal of Chinese Cinemas 2.1 (2008): 52-65.

Gilbert, Helen and Jacqueline Lo. Performance and Cosmopolitics: Cross-Cultural Transactions in Australia. Hampshire, UK: Palgrave Macmillan, 2007.

Greenblatt, Stephen, et al. The Norton Shakespeare. 2nd ed. New York and London: W. W. Norton \& Company, 2008.

Grotowski, Jerzy. "The Theatre's New Testament.” Dramatic Theory and Criticism: Greek to Grotowski. Ed. Bernard F. Dukore. New York: Holt, Rinehart and Winoton Inc., 1974. 978-96.

Hawkes, Terence. Meaning by Shakespeare. London: Routledge, 1992. 
Hoylewith, Martin. The Tragedy of Coriolanus, Edinburgh Playhouse-review (2013). http://www.ft.com/cms/s/2/d560115c-0a4f-11e3-9cec-00144feabdc0.html\# axzz31KEn3SsO. 23 May 2019.

Huang, Alexander (Alexa) C. Y. Chinese Shakespeares: Two Centuries of Cultural Exchange. New York: Columbia University Press, 2009.

" "King Lear (review) (dir. by David Tse for Yellow Earth Theatre and Shanghai Dramatic Arts Centre) at the Royal Shakespeare Theatre, November 2006.” Theatre Journal 59.3 (2007): 494-95.

-. "Review of King Lear (dir. by David Tse for Yellow Earth Theatre and Shanghai Dramatic Arts Centre) at the Royal Shakespeare Theatre, November 2006.” Shakespeare 3.2 (2007): 239-42.

Jones, Arthur. China gets on Bard: “Lear" features bilingual script, mixed cast (2006). http://variety.com/2006/legit/news/china-gets-on-bard-1117953713/. 21 August 2018.

Kennedy, Dennis, ed. Foreign Shakespeare: Contemporary Performance. Cambridge: Cambridge University Press, 1993.

Li, Ruru. "Millennium Shashibiya: Shakespeare in the Chinese-speaking World." Shakespeare in Asia: Contemporary Performance. Ed. Dennis Kennedy and Yong Li Lan. Cambridge: Cambridge University Press, 2010. 170-87.

- Shashibiya: Staging Shakespeare in China. Hong Kong: Hong Kong University Press, 2003.

Liang, Lia Wen-Ching. "Negotiating New Terrains: Yellow Earth Theatre's Lear's Daughters and King Lear." Contemporary Theatre Review 19.3 (2009): 289-97. 林，克欢. “历史·舞台·表演一评林兆华的文化意向与表演探索.”艺术评论 [Lin, Kehuan. "History, Stage and Performance: A Critique on Lin Zhaohua's Cultural Images and Performance Exploration.” Art Review.] 07 (2005): 53-57.

Ubersfeld, Anne. Reading Theatre. Trans. Frank Collins. Toronto: University of Toronto Press, 1999.

Willett, John, ed. and trans. Brecht on Theatre. New York: Hill and Wang, 1964. 